\title{
UNA AUTOBIOGRAFÍA RELIGIOSA FUERA DE LA NORMA autonomía y racionalidad en El libro de Recreaciones de María de San José
}

\author{
María Celeste Martínez CAlvo \\ Universidad de Granada
}

La producción textual dentro de los conventos de monjas abarca todo tipo de géneros, desde el teatro hasta la poesía ${ }^{1}$. Sin embargo, entre todos los géneros cultivados por monjas, destacan tanto por la abundancia de la producción como por sus características especiales las «autobiografías por mandato», textos autorreferenciales escritos por monjas por orden de sus confesores. En este artículo, exploraremos cómo funciona el mecanismo de la mayoría de las «autobiografías por mandato», y cómo María de San José, escritora del Libro de las recreaciones, libro que se suele introducir como exponente de este género, pudo hasta cierto punto escapar de la norma.

Si echamos un vistazo a la literatura crítica sobre este tema, veremos cómo no será hasta la última década del pasado siglo cuando se investigue a fondo la abundante producción de la literatura autorreferencial femenina dentro de la conventualidad española. Tal vez fue el «desconocimiento de las autobiografías espirituales como un conjunto representativo»» ${ }^{2}$ lo que hizo que la mayoría de estas obras fueran olvidadas por la crítica literaria, pero lo cierto es que el campo

${ }^{1}$ U. Jung, «La monja escritora: posibilidades y limitaciones», en M. Trambaioli y M. Tietz (eds.), El autor en el Siglo de Oro. Su estatus intelectual y social, Academia del Hispanismo, Vigo, 2011, pág. 192.

2 S. Herpoel, A la zaga de Santa Teresa: autobiografias por mandato, Rodopi, Ámsterdam/ Atlanta,1999, pág. 14. 
de la literatura autorreferencial religiosa es el único en el que destaca la literatura escrita por mujeres en los siglos XVI y XVII ${ }^{3}$, habiendo sólo como excepción algún ejemplo masculino ${ }^{4}$.

Sonja Herpoel define la «autobiografía por mandato» como un subgénero literario en el que «la autora ha de describir, en primera persona, una parte relativamente extensa de su itinerario espiritual, comenzando desde su nacimiento y primera juventud $\rangle^{5}$. No se pueden aplicar a estos textos el concepto de autoría actual, porque la influencia del confesor era determinante a la hora de configurar la obra. El director espiritual tenía libertad para alterar, destruir o publicar la autobiografia de su discípula ${ }^{6}$. Para Sonja Herpoel eso las convierte en un «medio de control y represión ideológica» ${ }^{7}$. Sin embargo, pienso, como señalan Isabelle Poutrin y Fernando Durán López, que el mandato de escritura, además de servir como instrumento de dominación, podía ser útil para la recopilación de materiales con vistas a procesos de beatificación o canonización y para la difusión de ciertas vidas ejemplares, en una empresa hagiográfica que daría mayor prestigio a la orden contemplativa. A partir de estas autobiografías, ciertos escritores, casi siempre pertenecientes a la rama masculina de la Orden, se encargaban de elaborar hagiografías, crónicas de la orden, sermones fúnebres y diversos textos con fines propagandísticos. Prueba de ello es que se solía encargar esta tarea a monjas que, además de superar la cincuentena, habían adquirido cierto prestigio dentro del mundo conventual ${ }^{8}$.

En sus inicios, en el siglo XVI, las carmelitas descalzas serían las principales cultivadoras de este género, porque «las autobiógrafas del siglo XVI son o bien parientes de la Fundadora o bien pertenecen al círculo reducido de sus confidentes y/o colaboradoras ${ }^{9}$. La Vida de Teresa de Jesús fue fundamental como modelo para la formación de la identidad como mujer dentro de los claustros y la primera obra de las «autobiografías por mandato» ${ }^{10}$. Sin embargo, a partir del siglo XVII, otras órdenes deciden cultivar también este género autobiográfico ${ }^{11}$. La fuerte proporción de autobiografías por mandato dentro de la orden carmelita descalza y agustina recoleta se debe en gran parte a la empresa de difusión hagiográfica

${ }^{3}$ M. H. Sánchez Ortega, La mujer y la sexualidad en el antiguo régimen: la perspectiva inquisitorial, Akal, Madrid, 1992, pág 85.

${ }^{4}$ F. Durán López, Un cielo abreviado. Introducción crítica a una historia de la autobiografía religiosa en España, Fundación Universitaria Española/Universidad Pontifica de Salamanca, Madrid, 2007 págs. 255-257; S. Herpoel, A la zaga de Santa Teresa, pág. 228; I. Poutrin, Le voile et la plume. Autobiographie et sainteté féminine dans l'Espagne moderne, Casa de Velázquez/Ciudad Universitaria, Madrid, 1995, pág. 25.

${ }^{5}$ S. Herpoel, loc. cit., pág. 21.

${ }^{6}$ F. Durán López, op. cit., págs. 66-68; I. Poutrin, op. cit., pág 115.

${ }^{7}$ S. Herpoel, A la zaga de Santa Teresa, pág. 223.

${ }^{8}$ F. Durán López, op. cit., págs. 81-82, 156-157; I. Poutrin, op. cit., págs. 20-22, 87, 126, 133.

${ }^{9}$ S. Herpoel, A la zaga de Santa Teresa, pág. 220.

${ }^{10}$ S. Herpoel, loc. cit., págs. 9, 30-31; M. J. de la Pascua Sánchez, «Escritura y experiencia femenina: la memoria de las descalzas en el Libro de las recreaciones de sor María de San José», Trocadero, 12-13, 2000-2001, págs. 312-313.

${ }^{11}$ S. Herpoel, loc. cit., pág 220. 
emprendida por estas dos órdenes ${ }^{12}$, siendo «congregaciones jóvenes, pujantes, renovadoras y que pugnaban por afirmarse frente a sus competidoras $\gg^{13}$.

Pero las relaciones de poder entre el confesor y su discípula no son siempre tan sencillas. Existe un modelo oficial en el que se muestra el sometimiento a la jerarquía, pero también diferentes estrategias de adaptación, subversión o cuestionamiento de la autoridad. Las tácticas defensivas también se utilizaban para protegerse de las altas instancias eclesiásticas, siendo la más temida de todas la Inquisición ${ }^{14}$. Creo que, como exponente de esta actitud inconformista, podemos situar a María de San José (Salazar) ${ }^{15}$, discípula directa de Teresa de Jesús. Ella ha sido incluida tanto por Herpoel, Poutrin y Durán López como cultivadora de este género literario ${ }^{16}$. Excepto por sus obras en prosa y algunos poemas, casi todas las obras literarias de esta escritora, entre las que se incluían un gran número de composiciones poéticas, obras teatrales y epístolas, se han perdido ${ }^{17}$. Su actividad como poeta se desarrolla desde los años 1562 a 1593, y se conservan unos 23 poemas, pero la mayoría de los escritos de madurez de María de San José se sitúan en torno a los años 1584 y 1603 , en Lisboa ${ }^{18}$.

12 I. Poutrin, op. cit., págs. 25-26.

${ }^{13}$ F. Durán López, op. cit., pág. 171.

${ }^{14}$ F. Durán López, loc. cit., pág. 115; S. Herpoel, A la zaga de Santa Teresa, págs. 7, 106-109.

${ }^{15}$ Se le suele añadir el apellido de Salazar para no confundirla con otra religiosa de la Orden, María de San José (Dantisco), hermana de Jerónimo Gracián o con María de San José (de Ávila), hermana de Julián de Ávila. A veces los estudiosos confunden a las tres monjas carmelitas. Simeón de la Sagrada Familia (ed.), en María de San José (Salazar), Escritos espirituales, Postulación general de la OCD, Roma, 1979, pág. 11. Para más información sobre la vida de María de Salazar (1548-1603), la autora objeto de nuestro estudio, recomiendo consultar las siguientes obras: M. del P. Manero Sorolla, «Diálogos de carmelitas: Libro de recreaciones de María de San José» [en línea], en A. Vilanova (coord.), Actas del X Congreso de la Asociación Internacional de Hispanistas, Barcelona 21-26 de agosto de 1989, 1, PPU, Barcelona, 1992, págs. 501-516. Centro Virtual Cervantes <cvc.cervantes.es/literatura/aih/pdf/10/ aih_10_1_057.pdf.> [19 nov. 2014]; M. del P. Manero Sorolla, «Exilios y destierros en la vida y en la obra de María de Salazar» [en línea], 1616: Anuario de la Sociedad Española de Literatura

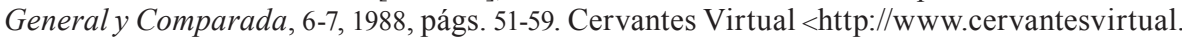
com/obra/exilios-y-destierros-en-la-vida-y-en-la-obra-de-mara-de-salazar-0/> [19 nov. 2014]; M. del P. Manero Sorolla, «María de San José y Luisa de la Cerda: Género, poder y espiritualidad en el inicio de la reforma teresiana», en P. M. Piñero Ramírez (ed.), Dejar hablar a los textos. Homenaje a Francisco Marquéz Villanueva, I, Universidad de Sevilla, 2005, págs. 441-471; I. Morujão, «Entre duas memórias: María de San José (Salazar) OCD, fundadora do primeiro Carmelo descalço feminino em Portugal» [en línea], Península: revista de estudos ibéricos, 0, 2003, páginas 241-260. Universidad de Oporto <ler.letras.up.pt/uploads/ficheiros/artigo12701.pdf $>$ [19 de noviembre de 2014]; D. de Pablo Maroto, Ser y misión del carmelo teresiano. Historia de un carisma, Espiritualidad, Madrid, 2011; M. de la C. Pérez García, María de San José, Salazar. La humanista colaboradora de Santa Teresa perseguida, Monte Carmelo, Burgos, 2009.

${ }^{16}$ F. Durán López, op. cit., pág. 225; S. Herpoel, A la zaga de Santa Teresa, pág. 77; I. Poutrin, op. cit., págs. 332-333.

${ }^{17}$ A. Weber, «Introduction», en María de San José Salazar, Book of the Hour of Recreation (trad. al inglés de A. Powell), University of Chicago, 2002, pág. 22.

${ }_{18}$ M. del P. Manero Sorolla (1991). «Un diálogo de carmelitas primitivo traducido al francés: Pour l'instruction de novices de María de San José (Salazar)» [en línea]. En F. Lafarga 


\section{El Libro de las recreaciones: entre el diálogo humanístico y la autobiogra- fía por mandato}

De 1585 es la redacción definitiva, aunque truncada, de su Libro de las recreaciones $^{19}$, obra en la que nos centraremos. Las Recreaciones es su primera obra importante en $\operatorname{prosa}^{20}$. Parece ser que sólo contamos con una copia manuscrita, hecha posiblemente por otra mano, que se conserva en la Biblioteca Nacional de Madrid del siglo XVII y con 131 hojas $^{21}$. Se han arrancado o desprendido los folios 125 y 126, que trataban de la fundación de Sevilla, y la copia se interrumpe de forma abrupta justo cuando va a comenzar la narración de la fundación de Lisboa ${ }^{22}$. En el manuscrito de las Carmelitas Descalzas de Sevilla, junto con otras obras, aparecen fragmentos del Libro de las recreaciones ${ }^{23}$. Es probable que comenzara su escritura en 1583, pero el grueso de la redacción es necesariamente de su etapa lisboeta, porque tanto los personajes como la ambientación se corresponden a la fundación de Lisboa ${ }^{24}$. También existe la posibilidad de que la fecha señalada de inicio de redacción del texto sea simbólica: «día del seráfico padre San Francisco, habiendo un año que este día se secó la flor del Carmelo» ${ }^{25}$. La función inicial del libro era la de ser una «vida espiritual» clásica, mandada por Jerónimo Gracián ${ }^{26}$, cuyo plan consistía en redactar «una memoria de mi

Maduell y M. L. Donaire Fernández (coords.), Traducción y adaptación cultural: EspañaFrancia, Universidad de Oviedo, 1991, pág. 370. Dialnet Unirioja < dialnet.unirioja.es/descarga/articulo/1113748.pdf.> [19 nov. 2014]; Simeón de la Sagrada Familia, op. cit., págs. 33-34.

${ }_{19}$ M. del P. Manero Sorolla, «Diálogos de carmelitas», pág. 503.

${ }^{20}$ Simeón de la Sagrada Familia, op. cit., págs. 27-31.

${ }^{21}$ Biblioteca Nacional de Madrid (Ms. 3508). María de San José. Libro de recreaciones.

22 Biblioteca Nacional de Madrid, loc. cit., fol. 131v.

${ }^{23}$ Simeón de la Sagrada Familia, op. cit., pág. 9.

24 M. del P. Manero Sorolla, «Diálogos de carmelitas», págs. 503 y 508; I. Poutrin, op. cit., página 429 .

${ }^{25}$ María de San José, «Obras completas» (ed. de Simeón de la Sagrada Familia), en Teresa de Jesús, Jerónimo Gracián, Ana de Jesús y María de San José, Humor y espiritualidad de la escuela teresiana primitiva, Monte Carmelo, Burgos, 1966, pág. 157.

${ }^{26}$ A partir de 1575, María de San José acompañará a Teresa de Jesús en sus fundaciones. Ese mismo año, en Beas de Segura, se produce el encuentro de Teresa de Jesús con Jerónimo Gracián, hecho que será determinante para ambas. Desde ese momento, Teresa de Jesús decidirá fundar en Sevilla y encontrará en Gracián un amigo y un nuevo conductor de la Orden. Para María de San José, conocer al padre Jerónimo Gracián será al mismo tiempo un consuelo, ya que hallará en él un buen guía espiritual, y una atadura, no por culpa del propio fraile, sino porque su relación de amistad será siempre utilizada como arma arrojadiza contra una monja que no se adaptaba a las jerarquías masculinas. Veáse, con respecto a este tema: V. Cohen Imach, «Con él a solas. Las cartas de Santa Teresa de Jesús a Jerónimo Gracián», [en línea], Anclajes, vol. 10, no 10, 2006, págs. 73-93. Anclajes <http://ojs.fchst.unlpam.edu.ar/ ojs/index.php /anclajes/issue/archive > [19 nov. 2014]; G. Díaz Díaz, Hombres y documentos de la filosofía española, tomo V. M-M-Ñ, CSIC, Madrid, 1995, págs. 168-169; S. Herpoel, «"Al fin soi muger”: Mujeres vistas por sí mismas» [en línea], en M. C. García de Enterría y A. Cordón Mesa (eds.), Actas del IV Congreso Internacional de la Asociación Internacional Siglo de Oro (AISO), (Alcalá de Henares, 22-27 de julio de 1996), Universidad de Alcalá, I, 1998, págs. 799-806. 
vida, en que le dijese la manera de proceder en la oración y las misericordias que Dios me ha hecho en ella ${ }^{27}$. La escritora soslaya la tarea encomendada, llegando a componer una obra que rompe con el esquema habitual de las «vidas espirituales». En el prólogo comenta los objetivos principales de la obra: «contar la vida de nuestra Santa Madre y las grandezas del Carmelo» ${ }^{28}$ y «pintar el trato y vida de nuestras religiosas $»^{29}$. Esta transgresión la hace situada desde la retórica de la humildad, ya que su principal argumento es que siente que su vida no es digna de ser narrada ${ }^{30}$.

El medio de escritura es «una manera de representación al vivo» ${ }^{31}$, es decir, un diálogo. Escogió este cauce genérico llevada por una conciencia de estilo y por el conocimiento del impacto que causaba el uso de las formas teatrales ${ }^{32}$. Era habitual que los escritores de diálogos declarasen la intención de reflejar una conversación de la vida real ${ }^{33}$. Las Recreaciones cumplen con las tres características fundamentales del diálogo: estructura actancial o interacción entre dos o más personajes; el desarrollo de un argumento; y las circunstancias de la representación ${ }^{34}$.

Es muy probable que las Recreaciones sean los primeros diálogos escritos por una mujer en lengua castellana ${ }^{35}$. Algunos estudiosos de la autora opinan que el empleo del diálogo humanístico lo adoptó de su introductor en el Carmelo, Jerónimo Gracián, que lo cultivó en numerosas obras, aunque la forma de diálogo que adopta María de San José, en la que ninguna voz carga con toda la autoridad, es bastante diferente de la de Jerónimo Gracián, más monológico ${ }^{36}$. Sin embargo, desde mi punto de vista, hay una cuestión que no ha sido suficientemente explorada. Si bien es cierto que esta forma de escritura llegó a María Salazar a través de Jerónimo Gracián, también lo es que las Recreaciones es un diálogo bastante

Dialnet Unirioja $<$ dialnet.unirioja.es/servlet/libro codigo $=2703>$ [19 nov. 2014]; M. del P. Manero Sorolla, «Exilios y destierros», pág. 55.

${ }^{27}$ María de San José, «Obras completas», pág. 158.

${ }^{28}$ María de San José, loc. cit., pág. 154.

${ }^{29}$ María de San José, loc. cit.

30 M. J. de la Pascua Sánchez, op. cit., págs. 298-299.

${ }^{31}$ María de San José, «Obras completas», pág. 154.

32 S. Schlau, «María de San José (María de Salazar) (1548-1603)». En L. Gould Levine, E. E. Marson y G. F. Waldman (eds.), Spanish women writers. A Bio-Bibliographical Source Book, Greenwood Press, Westport - CT/Londres, 1993, pág. 282.

33 J. Ferreras, «Elementos constitutivos, técnicas y recursos. Las marcas discursivas de la conciencia individualista en el diálogo humanístico del siglo XVI», en A. Rallo Gruss y R. Malpartida Tirado (coords.), Estudios sobre el diálogo renacentista español. Antología de la crítica, Universidad de Málaga, 2006, pág. 115.

${ }^{34}$ E. Kushner, «La función estructural del locus amoenus en los diálogos del Renacimiento», en A. Rallo Gruss y R. Malpartida Tirado (coords.), loc. cit., págs. 158-159.

${ }^{35}$ M. del P. Manero Sorolla, «Un diálogo de carmelitas primitivo traducido al francés», pág. 370; Idem, «Diálogos de carmelitas», pág. 505.

${ }^{36}$ M. del P. Manero Sorolla, «Diálogos de carmelitas», pág. 506; A. Weber, «On the Margins of Ecstasy: María de San José as (Auto)biographer», Journal of the Institute of Romances Studies, 4, 1996, pág. 258. 
anterior a la Peregrinación de Anastasio, la obra autobiográfica de Jerónimo Gracián, escrito también en forma de diálogo humanístico, dándose la posibilidad de que la escritura de María de San José influyese a su vez sobre la de Jerónimo Gracián. Debemos hablar, por tanto, de un diálogo humanístico algo contaminado por la forma de la autobiografía por mandato ${ }^{37}$, planteamiento en un principio no contemplado por su confesor, pero que luego le podría servir de inspiración para su obra. En las Recreaciones, la forma dialógica queda interrumpida momentáneamente por la narración de sucesos de su propia vida y por la biografía de Teresa de Jesús ${ }^{38}$, manifestándose así la intersección de los dos subgéneros literarios. De todos modos, la elección del cauce genérico del diálogo resulta, con respecto a las otras escritoras carmelitas, innovadora. Mientras que el estilo de las demás escritoras se acercaba a las formas de escritura que más conocían, es decir, la hagiografía, la carta y la confesión, María de San José se aleja de la primera persona y escoge un género literario normalmente reservado a sus compañeros masculinos, porque implicaba, en principio, una racionalidad que no se le solía atribuir precisamente a las mujeres ${ }^{39}$.

El plan inicial de las Recreaciones constaba de cinco partes: 1a) la narración de su vida; 2a) las virtudes del Carmelo; 3.) la biografía de Teresa de Jesús; 4.), los monasterios de la orden Descalza y $5^{\mathrm{a}}$ ) los efectos del amor de Dios ${ }^{40}$. Esta presentación se corresponde con la «praeparatio» de los diálogos humanísticos, que solía consistir en un prólogo o en un coloquio previo al tema del diálogo, en el que se presentaban las circunstancias de la ficción ${ }^{41}$. El diálogo se interrumpe al principio de la cuarta parte, ignorándose si la quinta parte llegó alguna vez a ser redactada ${ }^{42}$. Desde mi punto de vista, dada la frialdad y raciocinio con el que fue planteado el texto, fielmente ajustado al orden original, sí fue redactado, pero se decidió no incluirlo en la copia manuscrita. Las páginas restantes de Recreaciones iban, además, a tratar sobre la fundación en Lisboa. El manuscrito queda interrumpido justo en ese punto: «mas, porque no se me pase de la memoria la fundación de Lisboa [...], sabrán mis hermanas....»43. Con respecto a este final tan abrupto, podemos pensar, en un primer momento, que algún lector interesado en que no se desvelasen los detalles de esta fundación, decidió arrancar los folios restantes del manuscrito. Sin embargo, es una hipótesis difícil de sostener porque, si observamos detenidamente el manuscrito ${ }^{44}$, veremos que la

${ }^{37}$ A. Weber, loc. cit., pág. 256.

${ }^{38}$ María de San José, «Obras completas», págs. 256-309 y 310-350.

${ }^{39}$ Como ejemplo de la misoginia, pueden tomarse estas palabras de Luis de León en $L a$ perfecta casada: «el hombre [...] es la cordura y el valor, y el seso y el maestro, y todo el buen ejemplo de su casa y familia» (Luis de León, La perfecta casada, Madrid, Taurus, 1987, pág. 99).

${ }^{40}$ María de San José, «Obras completas», págs. 155-156.

${ }^{41}$ A. Rallo Gruss, La escritura dialéctica. Estudios sobre el diálogo renacentista, Universidad de Málaga, 1996, pág. 13.

${ }^{42}$ M. del P. Manero Sorolla, «Diálogos de carmelitas», pág. 508.

${ }^{43}$ María de San José, «Obras completas», pág. 305.

${ }^{44}$ Biblioteca Nacional de Madrid, op. cit., fol. 131v. 
interrupción de la redacción se da bastante antes que el final del folio, sin que se aprecien signos de violencia sobre la escritura o el papel. Además, en una obra posterior, Ramillete de Mirra, redactado en torno al año 1595, sí ahonda más en los detalles de la fundación de Lisboa ${ }^{45}$. Lo más probable es que el copista tuviese que abandonar la elaboración del manuscrito, bien por orden de algún superior o por alguna circunstancia que desconocemos. Más sospechoso todavía que este final brusco del manuscrito es el hecho de que algunos folios ${ }^{46}$ que hablaban sobre algunos detalles de la fundación de Sevilla, como hemos mencionado anteriormente, sí están arrancados o perdidos, pero no tenemos ninguna prueba que nos lleve a una conclusión definitiva.

Además de las cuatro partes que aparecen en el texto, tenemos la presencia de nueve recreaciones. Cada recreación consiste en una escena de diálogo que termina con la llamada a la oración, y se corresponde con un día diferente ${ }^{47}$. La recreación, una destacada innovación que introdujo Teresa de Jesús en la regla primitiva, consistía en dos periodos de tiempo, una hora después de la comida y después de la cena, en los cuales se procuraba tener una charla distendida entre todas las hermanas del convento ${ }^{48}$. La división de los diálogos en varias jornadas, a través de las cuales se remarca el transcurso del tiempo, era habitual en el diálogo humanístico, para crear así la ilusión de un proceso dialéctico ${ }^{49}$. A. Weber plantea la posibilidad de que esta ordenación en recreaciones sea posterior a la escritora $^{50}$. Desde mi opinión, dado que cada una de las nueve recreaciones queda señalizada en el propio texto, esta ordenación sí se corresponde con la intención original de María de Salazar. Esta decisión no responde sólo a gustos estéticos, sino que, a efectos de verosimilitud, es el único espacio en el que puede situarse un coloquio conventual ${ }^{51}$, en aquellos huecos de tiempo libres de las obligaciones y rezos propios de la Regla carmelita. El diálogo siempre se sitúa en un espacio y un tiempo que invita al intercambio verbal ${ }^{52}$. Las cuatro partes quedan encuadradas dentro de nueve recreaciones de la siguiente forma: la primera parte, corresponde a la primera y segunda recreaciones; la segunda parte, a la tercera, cuarta, quinta y séptima recreación; la tercera parte, a la octava recreación; y la cuarta parte, a la novena recreación.

El diálogo se sitúa en un jardín conventual, para M. del P. Manero Sorolla descrito con todos los tópicos del locus amoenus, al que se añaden los propios del espacio religioso donde se sitúa ${ }^{53}$. La ambientación del diálogo es un

${ }^{45}$ Simeón de la Sagrada familia, op. cit., págs. 31-32.

${ }^{46}$ En la Biblioteca Nacional de Madrid, op. cit., desde el fol. 124 hasta el fol. 127, las hojas están desaparecidas.

${ }^{47}$ S. Schlau, op. cit., pág. 282.

${ }^{48}$ I. Moriones, Teresa de Jesús. Maestra de perfección, Teresianum, Roma, 2012, pág. 46.

${ }^{49}$ A. Rallo Gruss, op. cit., págs. 14-15.

${ }^{50}$ A. Weber, «Introduction», pág. 23, n. 33.

${ }^{51}$ M. del P. Manero Sorolla, «Diálogos de carmelitas», pág. 508.

52 A. Rallo Gruss, op. cit., pág. 14.

${ }^{53}$ M. del P. Manero Sorolla, «Diálogos de carmelitas», pág. 508. 
elemento más que ayuda a definir el carácter de la conversación ${ }^{54}$. Sin embargo el ambiente es otoñal: «el tiempo no era para buscar la frescura y campos, que en la primavera suele ser deleitoso, empero a la plática que tenían ayudaba la soledad y ruido del viento» ${ }^{55}$. Esta ambientación corresponde al mes de octubre, mes en que Teresa de Jesús falleció, y desde mi punto de vista, resulta poco frecuente frente a una concepción del paisaje cerrada y casi siempre primaveral.

En el diálogo intervienen cinco interlocutoras: Gracia, alter-ego de la escritora, Justa, Atanasia, Josefa y Dorotea. Parece ser que detrás de estos tres últimos nombres están las hermanas Mariana de los Santos, Inés de San Elíseo y Blanca de Jesús, que vinieron desde Sevilla a Lisboa para la fundación del convento de San Alberto con María de Salazar ${ }^{56}$. Los personajes quedan bastante bien definidos, más por sus palabras y por los otros interlocutores que por las descripciones objetivas de la tercera persona del texto, que son bien escasas. Gracia es señalada en el marco del diálogo como «la que más moza parecía» ${ }^{57}$, y es la que lleva la voz principal, representando así a la propia escritora. Era habitual en el diálogo humanístico que el personaje principal fuera un reflejo del propio autor ${ }^{58}$. La hermana Justa parece ser el contrapunto de Gracia, o su «oponente, a la vez que alter-ego» ${ }^{59}$. Gracia la define de esta forma: «pues es tu nombre Justicia, para dar a cada cosa lo que es suyo» ${ }^{60}$. El sobrenombre de Gracia apunta a tres significados verosímiles: al don divino; al sentido del humor; o como un juego de palabras que alude al nombre de Jerónimo Gracián. El sobrenombre de Justa puede hacer referencia tanto a la justicia como a la estrechez de miras ${ }^{61}$, acomodándose más la segunda acepción al carácter del personaje. Justa adopta, en muchas ocasiones, el papel de novicia inexperta. Hay partes del texto que van dirigidas a las hermanas recién profesas en el convento. Parece ser que, a María de San José, como priora, le pareció útil el género de diálogo como herramienta didáctica, y decidió aplicarlo en una obra posterior, Instrucción de novicias, fechada en 1602 y titulada originalmente Diálogo entre dos religiosas que Gracia y Justa se llaman, sobre la oración y mortificación con que se deben criar las novicias. En ella, la escritora recoge los personajes de Justa y Gracia de nuevo para extenderse sobre aquellos temas que más le preocupaban como priora en la formación de las nuevas generaciones de carmelitas. Justa retoma su papel de novicia y Gracia lleva aquí todo el peso del magisterio ${ }^{62}$.

\footnotetext{
${ }^{54}$ E. Kushner, op. cit., pág. 163.

${ }^{55}$ María de San José, «Obras completas», pág. 157.

${ }^{56}$ M. del P. Manero Sorolla, «Diálogos de carmelitas», pág. 509.

${ }^{57}$ María de San José, «Obras completas», pág. 157.

58 A. Rallo Gruss, op. cit., pág. 15.

${ }^{59}$ M. del P. Manero Sorolla, «Diálogos de carmelitas», pág. 509.

${ }^{60}$ María de San José, «Obras completas», pág. 160.

${ }^{61}$ A. Weber, «Introduction», págs. 18-19, 18, n. 25.

${ }^{62}$ María de San José, Instrucción de novicias, Instituto Histórico Teresiano, Roma, 1978. Esto no era nada nuevo. Desde la Edad Media, eran frecuentes los diálogos entre un monje
} 
Atanasia, que aparece a partir de la tercera recreación para continuar durante todo el resto de la obra, representa la sabiduría. Era necesaria para acometer todo el resto del diálogo: así el texto tenía más variedad y no se echaba en Gracia, el alter-ego de la escritora, todo el peso de la cultura y conocimiento. Es descrita como «venerable» ${ }^{63}$ y se declara en el texto que «como maestra la tenían» ${ }^{64}$. Josefa y Dorotea sólo aparecen durante la primera recreación y son descritas en conjunto, sin valores diferenciadores significativos. Tanto es así, que M. Serrano y Sanz describe las Recreaciones como «varios diálogos entre Justa, Gracia y Atanasia» ${ }^{65}$. Siguiendo las prácticas del diálogo humanístico ${ }^{66}$, las diferentes interlocutoras mantienen entre sí una relación de amistad que permite superar todas las barreras sociales y culturales que pudiera haber.

Otros personajes fundamentales en el texto, además de las interlocutoras, son la «madre Angela», refiriéndose con este sobrenombre a Teresa de Jesús, y el «padre Eliseo», en este caso refiriéndose a Jerónimo Gracián. Los sobrenombres ya fueron inventados en el intercambio epistolar entre ambos religiosos: "Cuando nos escribíamos la madre Teresa y yo, por manera de cifra mudábamos los nombres» ${ }^{67}$. En el primer caso, María de Salazar lo evidencia: «Teresa de Jesús, de quien dos hijas suyas [...] hablaban de ella debajo del nombre de Angela»68; mientras que, en el segundo caso, se deduce del contexto de la obra, ya que Gracián era el principal confesor y amigo de María de San José. También las interlocutoras aluden a tres hermanas del convento, con los nombres de Inocencia, Cándida y Basiana, refiriéndose, seguramente, a compañeras de su monasterio.

\subsection{Racionalidad y vida mística en las Recreaciones}

En la segunda y tercera recreación, y en casi toda la séptima recreación, se trata el tema de la oración y de la vida interior dentro del Carmelo. Es de destacar que el espacio que dedica María de San José a la oración y a los fenómenos sobrenaturales es escaso en comparación con otras religiosas carmelitas. Aun así, es demasiado arriesgado aventurar que, para el conjunto de la obra, no resulte significativa la parte dedicada a la vida interior, ya que su final se encuentra perdido. María de San José pretendía ampliar en la quinta parte este tema: «porque habrá otro lugar donde digamos de los efectos que éste divino amor hace» ${ }^{69}$. No pensemos que, por tratar poco de la oración, le resta importancia:

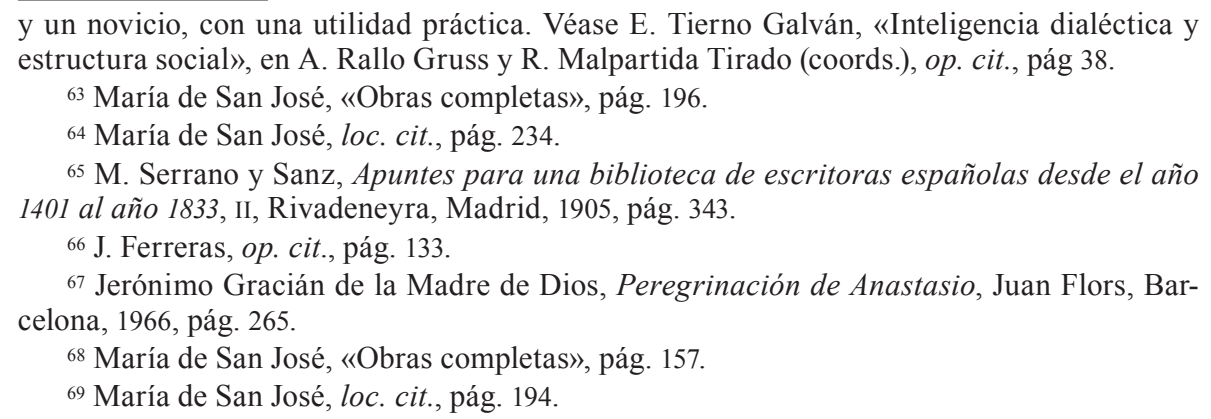


«no pienses que es perder tiempo tratar de estas cosas, que, pues es la más importante para la vida espiritual la oración $»^{70}$. Una de las causas que le impulsó a convertirse en carmelita, es, precisamente, «que aquellas religiosas tenían de constitución tener oración mental, a que yo estaba muy aficionada sin saber lo que era $\rangle^{71}$. No es ocioso que hable de la oración mental cuando narra su vida, ya que, frente a otras corrientes religiosas, las carmelitas tenían una visión providencialista de la importancia de su vida de oración y recogimiento. Esta cosmovisión les permitiría soportar el ascetismo riguroso de la Orden ${ }^{72}$. Sin embargo, se atiene a los dictados de la Iglesia: «de todo me recelo, y sólo echo mano de lo que la Iglesia me ha enseñado» ${ }^{73}$. De esta forma, además de mostrar su carácter cauteloso, pretende protegerse por si el texto fuese sometido a juicio. En la tercera recreación, se habla de cómo se produce la oración, de las posibilidades de interpretación de la Biblia y sobre en qué consiste la falsa devoción. Si María de Salazar en la segunda recreación ha puesto todas las afirmaciones importantes en boca de Gracia, a partir de la tercera recreación prefiere darle voz a Atanasia para hablar de la oración y de sus diferentes efectos ${ }^{74}$. Pasa, por tanto, del papel de maestra al papel de alumna. Este hecho puede deberse bien a una retórica de la humildad, o incluso cabe la posibilidad de que escribiera este fragmento siguiendo los consejos de alguna hermana del convento más experimentada en la oración. Lo importante es señalar que se produce un magisterio mutuo entre mujeres. Atanasia, Gracia y Justa se enseñan las unas a las otras, con el añadido que se hace, casi siempre en boca de Gracia, de las citas de Teresa de Jesús sobre los diferentes aspectos de la devoción 75 .

La parte dedicada al encuentro con Dios de la recreación séptima enseña la oración partiendo de una estructura en siete partes. Enumera las siete partes sin especificar la fuente exacta: «dicen que ha de tener siete partes, que son: preparación, lección, meditación, contemplación, hacimiento de gracias, petición, epílogo $\gg^{76}$. En un principio, esta división parece proceder de Jerónimo Gracián, pudiéndosela haber comunicado oralmente. De hecho, en el tratado de Jerónimo Gracián (1586), publicado después de las Recreaciones ${ }^{77}$, y titulado De la oración mental, sus partes y sus condiciones, se especifica: «Tiene pues la oración

\footnotetext{
${ }^{70}$ María de San José, loc. cit., pág. 239.

${ }^{71}$ María de San José, loc. cit., pág. 173.

72 A. Weber, «Introduction», pág. 15. Con respecto al fuerte enfrentamiento entre la vía ascética tradicional y el recogimiento dentro de la religiosidad española de los siglos XVI y XVII, se puede ampliar información sobre el tema en las imprescindibles obras de M. Andrés Martín, Historia de la mística de la edad de oro en España y América, Biblioteca de Autores Cristianos, Madrid, 1994, y Los recogidos: nueva visión de la mística española (1500-1700), Fundación Universitaria Española/Seminario Suárez, Madrid, 1975.

${ }_{73}$ María de San José, «Obras completas», pág. 182.

74 María de San José, loc. cit., pág. 198.

75 María de San José, loc. cit., pág. 200.

76 María de San José, loc. cit., pág. 240.

77 A. Pego Puigbó, El renacimiento espiritual: introducción literaria a los tratados de oración españoles (1520-1566), CSIC/Instituto de la Lengua Española, Madrid, 2004, pág. 208.
} 
mental siete partes, las cuales los autores llaman preparación, lección, meditación, contemplación, hacimiento de gracias, petición, conclusión o epílogo» ${ }^{78}$. Aun a pesar de esta coincidencia, en la práctica, la exposición de María de San José no se asemeja demasiado a este tratado de Jerónimo Gracián, organizado sistemáticamente. La clave de donde podían provenir sus influencias está en una obra posterior, Instrucción de novicias. En uno de los capítulos, «De la oración mental y sus partes $»^{79}$, aunque titulado igual que la obra de Jerónimo Gracián, se especifican sus fuentes para la oración mental:

Infinidad de libros hay [...], y los del Padre fray Luis de Granada satisfacen a todo género y calidad de gente. Y si por ser varón y docto no se acomoda tanto con tu lenguaje, Dios nos ha dado una mujer doctora, graduada en la escuela del Espíritu Santo, con cuya ciencia salió tan sabia la grande Teresa, que espero ha de ser grande y célebre en la Iglesia de Dios, no solo por la vida, más también por la doctrina que dejó escrita ${ }^{80}$.

No quiero decir con esto que no influyese en María de San José la clasificación de Jerónimo Gracián, pero sí señalar que, a la hora de intentar transmitirla a sus discípulas, su estilo está mucho más cercano al de Luis de Granada, sin olvidar la influencia de Teresa de Jesús. Desde que la oración mental se divulga en el cristianismo, hay dos tendencias dominantes en los tratados de oración: o se opta por intentar guiar a través de un método más emotivo y basado en la experiencia personal de cada creyente, o se plantea un esquema muy estructurado para que el lector lo siga de una manera estricta ${ }^{81}$. María de San José, al igual que fray Luis de Granada o Teresa de Jesús, se sitúa desde un punto de vista intermedio, sin llegar a una sistematización rigurosa pero sin profundizar en las experiencias personales.

Partiendo de esta división, se corrigen los errores en la oración más comunes de los principiantes y se dan algunos consejos prácticos. Justa, señalada como una novicia inexperta, es la que hace las mayorías de las preguntas que podría plantearse toda aquella recién iniciada en la vida carmelita ${ }^{82}$. Con un sentido didáctico, Atanasia va describiendo la naturaleza de cada una de las partes de la oración $^{83}$. La principal preparación debe ser «la limpieza del alma» ${ }^{84}$. Muy importante en la lección es que «todo lo que meditáremos sea cosa leída y enseñada

78 Jerónimo Gracián de la Madre de Dios, «De la oración mental, y de sus partes y condiciones», en Lámpara encendida. Compendio de la perfección, Juan de la Cuesta, Madrid, 1604, fol. 73 r.

${ }^{79}$ María de San José, Instrucción de novicias, págs. 123-170.

${ }^{80}$ María de San José, loc. cit., págs. 123-124.

81 J. Varo Zafra, Alegoría y metafísica, Universidad de Granada, 2007, pág. 447.

${ }^{82}$ María de San José, «Obras completas», págs. 240-241.

${ }^{83}$ María de San José, loc. cit., págs. 242-247.

${ }^{84}$ María de San José, loc. cit., pág. 241. 
de los santos doctores ${ }^{85}$. María de San José da una importancia destacable al papel de las obras de espiritualidad durante el proceso de la oración: «es excelentísimo ejercicio el leer, y es bien que los espirituales no lo dejen» ${ }^{86}$. Luis de Granada también instaba a la lectura de libros espirituales ${ }^{87}$. La meditación sería necesaria sobre todo a los principiantes en la oración, para acomodarse a la voluntad divina ${ }^{88}$.

Cuando llega a la contemplación, el texto pasa de ser descriptivo a alegórico. Primero, la autora pinta el siguiente cuadro: «la oración [...] es semejante a un pomo oloroso, donde, mezclando un licor de aguas olorosas con otras especies [sic] aromáticas, lo ponemos sobre las brasas donde también hay ceniza» ${ }^{89}$. A continuación, explica cada uno de los distintos elementos según su esquema de la oración: la buena voluntad de llegar a Dios y la humildad necesarias para la preparación de la oración son representados respectivamente por el agua y la ceniza; la lección, simbolizada por todos los elementos conjuntamente preparados; la meditación, por el prendimiento y mantenimiento del fuego; y el vapor, por la contemplación ${ }^{90}$. La contemplación para la escritora es como el «alma en un instante se llena de suavidad sin saber cómo ni a qué sabe lo que se comunica»»1. La contemplación haría que «el alma esté como suspensa, y las potencias, aunque no del todo, perdidas ${ }^{92}$. A los siguientes dos pasos, el hacimiento de gracias y la petición, les dedica muy poco espacio. El epílogo consiste en rememorar los dones concedidos durante la oración ${ }^{93}$.

Parece que, en el pasaje de la contemplación, María de San José ha perdido algo de frialdad, pero, si la comparamos, por ejemplo, con Teresa de Jesús, aunque se sirve también de alegorías, veremos cómo esta última utiliza un lenguaje mucho más rico a la hora de expresar distintos matices en los grados de oración. Como contraste, puede servirnos este pasaje en el que el fuego le sirve a Teresa de Jesús para expresar los momentos en los que las almas más perfeccionadas sufren momentos de sequedad:

Ansí son las almas que digo; aunque fuese muy a su costa, querrían traer leña para que no cesase este fuego. Yo soy tal que, aun con pajas que pudiese echar en él, me contentaría; y ansí me acaece algunas muchas veces [...]. Pues no tienen poco trabajo a ánimas que da Dios por su bondad este fuego de amor suyo en abundancia, faltar fuerzas corporales para hacer algo por Él. Es una pena bien grande; porque, como

\footnotetext{
${ }^{85}$ María de San José, loc. cit., pág. 243.

86 María de San José, loc. cit.

${ }^{87}$ Luis de Granada, Obras, II: Libro de la oración y meditación, Imprenta de la viuda e hija de Gómez Fuentenebro, Madrid, 1906, págs. 301-302.

88 María de San José, «Obras completas», pág. 243.

${ }^{89}$ María de San José, loc. cit., pág. 245.

${ }^{90}$ María de San José, loc. cit., págs. 245-246.

${ }^{91}$ María de San José, loc. cit., pág. 245.

92 María de San José, loc. cit., pág. 246.

93 María de San José, loc. cit.
} 
le faltan fuerzas para echar alguna leña en este fuego y en ella muere porque no se mate, paréceme que ella entre sí se consume y hace ceniza y se deshace en lágrimas, y se quema, y es harto tormento, aunque es sabroso $^{94}$.

María de San José ${ }^{95}$ cuenta algunas impresiones que ha recibido durante la oración, pero sin caer nunca en ningún extremo. Lo cierto es que, cuando se describe en boca de Gracia las sensaciones de sus encuentros con Dios ${ }^{96}$, no se encuentra la altura mística de otros textos carmelitanos. Parece que María de San José tenía una visión intimista y poco espectacular de lo que debía ser la oración para una religiosa ${ }^{97}$, pero también es cierto que señala que no lo ha publicado todo sobre su vida interior: «ni tengo que decir más, ni es bien que las particularidades que el alma pasa con Dios, ella lo diga en público» ${ }^{98}$. También Luis de Granada recomendaba «tener mucho secreto en callar los favores y regalos que el Señor algunas veces suele hacer a los suyos en oración» ${ }^{99}$.

No es ésta, sin embargo, la línea general de escritura en las autobiografías por mandato, en las que predominaba el deseo de encandilar al lector a través de la emotividad ${ }^{100}$. Desde Teresa de Jesús, la fundadora de este género, que, aunque prudente, narra en diversos pasajes sus encuentros con lo divino, hasta otras seguidoras como Ana de San Bartolomé o María de la Cruz, aparecen reflejados numerosos fenómenos místicos, entre los que destacamos los referidos al Niño Jesús, a la relación esponsal con Cristo y a la Pasión ${ }^{101}$. Los ejemplos son innumerables y es imposible referirlos todos en este artículo, pero podemos enseñar una muestra. María de la Cruz, cantando el himno «O gloriosa domina», se encuentra con el Niño Jesús, en una visión que puede resultar algo chocante para el lector actual:

Me pareçió de presto estar el niño Jesús muy llegado a mí de suerte que la sacratísima Virgen le tiene en sus brazos, llegado mucho al pecho. A mí me pareçió estar en el mío indignísimo este sacro Niño, y su rostro

\footnotetext{
${ }^{94}$ Teresa de Jesús, Libro de la vida, Cátedra, Madrid, 2006, pág. 364.

${ }_{95}$ María de San José, «Obras completas», págs. 189-191.

${ }^{96}$ María de San José, loc. cit., págs. 179-181.

${ }^{97}$ A. Weber, «Introduction», pág. 19.

98 María de San José, «Obras completas», pág. 191.

${ }^{99}$ Luis de Granada, op. cit., pág. 418.

${ }^{100}$ F. Durán López, op. cit., 183.

${ }^{101}$ L. González-Carvajal Santabárbara, Mil gracias derramando: Experiencia del Espíritu ayer y hoy, Universidad Pontificia de Comillas, Madrid, 2011, pág. 138; A. Rubial García, Profetisas y solitarios. Espacios y mensajes de una religión dirigida por ermitaños y beatas laicos en las ciudades de Nueva España, Universidad Nacional Autónoma de México/Fondo de Cultura Económica, 2006, pág. 614; R. Sanmartín Bastida, La representación de las místicas: Sor María de Santo Domingo en su contexto europeo, Real Sociedad Menéndez Pelayo, Santander, 2012, págs. 136, 138, 155, 195.
} 
divino, que entonçes sí me parece le vide, llegadísimo y muy pegado a mi indigno pecho, quiriendo resposar y descansar en él ${ }^{102}$.

En cuanto a Jesucristo como esposo, es conocido el pasaje en el que se muestra celoso ante Teresa de Jesús: «quiso el Señor darme a entender que no me convenían aquellas amistades [...]: representóseme Cristo delante con mucho rigor, dándome a entender lo que de aquello le pesaba» ${ }^{103}$. En Ana de San Bartolomé, la relación esponsal con Jesús se torna fascinante, ya que evoluciona paulatinamente. En su adolescencia, se promete en matrimonio con el Niño Jesús ${ }^{104}$. Siempre es descrito con el sustantivo «hermosura»: «ermosísimo» ${ }^{105}$, «ermoso que rrovava el coraçón» ${ }^{106}$. Más adelante, Jesucristo toma la actitud de un enamorado, e introduce la mano en su corazón: «Venía tan a pasito y como detrás, como pudiera venir otro onbre que estuviera enamorado a açer una graçia a su esposa. Y llegándose más, echó su mano sobre mi coraçón y pareçió an me avía arrancado» ${ }^{107}$. En cuanto a la Pasión, también son muy abundantes las imágenes de tipo corporal y afectivo. Cristo se le aparece a Ana de San Bartolomé «coronado de espinas, atadas las manos y vna soga a la garganta y todo llagado» ${ }^{108}$, y a María de la Cruz «acabado de açotar, el qual tenía todo su cuerpo sagrado desollado y hecho una pura llaga, sin aver parte ninguna en él sana» ${ }^{109}$.

También es cierto que la racionalidad de María de San José nace de un carácter cauteloso. La escritora refiere cómo habría sido avisada por Dios antes de su marcha a Lisboa: «llevad monjas asidas a las cosas de la fe y desasidas de milagros e invenciones porque hay allí necesidad de fe» ${ }^{110}$. Creo que se refiere a las monjas de la Anunciada, cuya priora era María de la Visitación, una falsa mística. Precisamente, por haber residido en la Anunciada, María de San José tendrá un papel principal en el desenmascaramiento entre el 12 y 14 de octubre de 1588 de María de la Visitación, la llamada «monja de las llagas», priora del convento de dominicas de la Anunciada ${ }^{111}$. No le interesaba atraer a la orden

${ }_{102}$ María de la Cruz, «Libro I: Vida de la Venerable Madre María de la Cruz, O.C.D. Escrita toda de su mano». Estudio y edición paleográfica. En Manuel Morales Borrero. El convento de Carmelitas Descalzas de Úbeda y el Carmelo femenino en Jaén. María de la Cruz, o.C.D. Su vida y su obra, II, Diputación Provincial de Jaén/Instituto de Estudios Giennenses, 1995, pág. 79.

103 Teresa de Jesús, op. cit., pág. 160.

${ }^{104}$ Ana de San Bartolomé, Obras Completas, 1, Teresianum, Roma, 1981, págs. 285-286.

${ }^{105}$ Ana de San Bartolomé, loc. cit., págs. 296, 298, 338.

106 Ana de San Bartolomé, loc. cit., pág. 296.

${ }^{107}$ Ana de San Bartolomé, loc. cit.

${ }^{108}$ Ana de San Bartolomé, loc. cit., pág. 302.

${ }^{109}$ María de la Cruz, op. cit., pág. 67.

110 María de San José, «Obras completas», pág. 191.

${ }^{111}$ M. del P. Manero Sorolla, «María de San José y Luisa de la Cerda», pág. 456; M. de la C. Pérez García, op. cit, págs. 365-366; I. Poutrin, op. cit., pág. 332; A. Weber, «Introduction», pág XXX. 
del Carmelo a mujeres excesivamente crédulas que llamasen demasiado la atención de la Inquisición. Para la escritora, el misticismo de la descalcez no radica en la sucesión continua de milagros, sino en una fe interior y silenciosa. De ahí que decida no centrarse en las Recreaciones en estos fenómenos, sino que pretenda enfocar a las futuras generaciones de carmelitas hacia una visión más ascética e íntima del encuentro con lo divino. Luis de Granada también advertía en su Libro de la oración y meditación lo siguiente:

Si no debemos desear consolaciones y deleites espirituales para sólo parar en ellos, mucho menos debemos desear visiones, o revelaciones, o arrebatamientos y cosas semejantes, porque es evidentísimo principio para todas las ilusiones del enemigo ${ }^{112}$.

El tema del «discernimiento espiritual», es decir, la distinción entre los fenómenos sobrenaturales que podían venir de una fuente benigna o maligna, es algo que preocupaba a los escritores carmelitas. Teresa de Jesús actuó con mucha prudencia en este sentido y siempre buscó asesoría en diversos teólogos para no tomar un camino heterodoxo que la apartara de la Iglesia ${ }^{113}$.

María de San José huye también de un ascetismo excesivamente orientado al castigo corporal, que puede ser causa de enfermedades físicas y mentales ${ }^{114}$. Asimismo, Luis de Granada recomendaba «discreción» ${ }^{115}$ a la hora de poner en práctica «los tiempos de oración y las vigilias y asperezas corporales»"116, para no desfallecer durante el rezo ${ }^{117}$. Parece ser que, sin embargo, lo habitual en las «autobiografías por mandato» era narrar las penitencias, muchas veces llevadas al sufrimiento extremo, que se toman durante el noviciado ${ }^{118}$. A pesar de que tanto Ana de San Bartolomé como María de la Cruz fueron en su juventud reprendidas por sus confesores, el hecho de que aparezcan en sus textos es una señal que indica que el ascetismo extremo no eran tan mal visto por los dirigentes religiosos ${ }^{119}$.

112 Luis de Granada, op. cit., pág. 417.

${ }^{113}$ M. Herráiz, Discernimiento espiritual en Teresa y Juan de la Cruz, Instituto Teológico de Vida Religiosa, Gasteiz-Vitoria, 2008, pág. 76.

114 María de San José, «Obras completas», págs. 47-249.

${ }^{115}$ Luis de Granada, op. cit., pág. 423.

116 Luis de Granada, loc. cit.

117 Luis de Granada, loc. cit., págs. 423-425.

118 Ana de San Bartolomé, op. cit., págs 293-294; María de la Cruz, op. cit., pág. 51.

119 Con respecto al tema de la disciplina física, puede resultar muy representativo este párrafo de R. Sanmartín Bastida: «Como el cuerpo de Cristo, el de las visionarias es así flagelado, forzado a arrodillarse durante horas y a vivir ayunos completos. No es de extrañar que con estos comportamientos les sobrevinieran a las visionarias importantes problemas de salud. Por estos sacrificios, y por las enfermedades que les manda Dios, se hacen físicamente débiles, algo que se asocia a su fuerza espiritual y las aísla de los otros» (R. Sanmartín Bastida, op. cit., pág. 203). 


\section{Síntesis y conclusión}

María de San José es, en este aspecto, un caso raro con respecto a la mayoría de las vidas espirituales. No sabemos si esta frialdad o racionalidad con respecto a los fenómenos místicos se debe a la prudencia o a su propia experiencia, pero lo cierto es que aquí no nos encontraremos con un catálogo de «gracias»o «mercedes» como sucede en gran parte de las autobiografías por mandato ${ }^{120}$, sino con la exposición de un método de oración que, aunque esté más o menos abierto, pretende servir de cauce para la difusión de una religiosidad más contenida. En este caso, se rompe el tópico de que la religiosidad femenina es siempre afectiva y corporal frente a la visión más intelectual de los religiosos masculinos. Esta distinción entre los religiosos de uno y otro sexo nace, en gran parte, apoyada por unos textos que siguen un modelo emotivo y experiencial, pero también en el prejuicio masculino que se extiende desde Aristóteles y que ha llegado subrepticiamente hasta nuestros días de que las mujeres carecen de capacidad intelectual ${ }^{121}$. Con esto, lo que queremos decir es que el lenguaje más afectivo de ciertas religiosas no se corresponde tanto con un supuesto "carácter femenino" que las convierte en menos racionales que sus homólogos masculinos, sino que su escritura responde a las expectativas que su confesor podía tener como narratario. En la mayoría de las autobiografías por mandato, vemos, por tanto, más que las propias inquietudes de las religiosas, el cumplimiento del modelo impuesto por una mirada ajena, marcado por la saturación emocional ${ }^{122}$. Podemos decir, por tanto, que muchas escritoras se reflejaban en un espejo torcido por su propio confesor.

Debemos preguntarnos entonces cómo fue posible que María de San José escapara, en cierto modo, del modelo impuesto a sus compañeras, al menos en el silencio de su claustro, aunque luego no pudiera proyectarla más allá del muro conventual. No debemos olvidar que, en cierto modo, por lo que se deduce de los avatares de su vida y por el silenciamiento que hubo sobre esta escritora hasta bien entrado el siglo Xx, que su presencia no fue muy bien digerida durante un largo periodo de tiempo por la historia carmelitana. En este sentido, no tuvo tanta suerte, o tanta pericia, como Teresa de Jesús que, aunque igualmente autodidacta, supo sortear con más inteligencia los impedimentos que la época le impuso por ser mujer. A. Weber plantea que la mejor táctica defensiva de Teresa de Jesús no fue ya el hecho de hacer suyos estereotipos femeninos como la timidez, la ignorancia o la debilidad mental, sino saber escapar del mito de la mujer

${ }^{120}$ I. Poutrin, op. cit., pág. 121.

${ }^{121}$ C. Baranda, «La varia historia de sanctas e illustres mugeres de J. Pérez de Moya (1583)», en B. Fouques y A. Martínez González (eds.), Imágenes de mujeres. Images de femmes, Universidad de Caen-Laboratoire d'études italiennes, ibériques et ibéro-américaines, 1998, pág. 24.

${ }^{122}$ L. C. Álvarez Santaló, Así en la letra como en el cielo. Libro e imaginario religioso en la España moderna, Abada, Madrid, 2012, págs. 40-41; F. Durán López, op. cit., pág. 189. 
como sujeto u objeto de seducción ${ }^{123}$. Como hemos podido ver, la obra de María de San José no oculta su cultura general, aunque utilice algunos procedimientos para evadir la censura, como la atribución a otro personaje distinto de Gracia, su alter-ego, la exposición de sus conocimientos sobre la oración.

No podemos obviar que, aun con su carácter independiente, nada hubiera podido conseguir sin dos circunstancias esenciales de la vida de la monja: su importante formación cultural y la amistad que tenía con su padre espiritual, Jerónimo Gracián ${ }^{124}$. La cultura le dio las herramientas lingüísticas necesarias para poder desarrollar con pericia su propia forma de pensar; $y$, con respecto a la amistad de Jerónimo Gracián, creo que, aunque el mandato fue real, ella sentía que tenía cierto margen de libertad para desarrollar sus inquietudes literarias, escapando en cierto modo de la orden inicial. Por el final tan abrupto de las Recreaciones, nos queda la duda de si su confesor aceptó la forma dada a la obra por su discípula o de si, por el contrario, le recomendó dejarla sin terminar. Sí, es cierto que la presencia de Jerónimo Gracián fue necesaria para que pudiera llevar a cabo su obra, pero no parece que fuera determinante a la hora de su ejecución, donde mantuvo ciertos criterios propios. A lo largo de este artículo, he pretendido demostrar que dos aspectos del texto que pudieran ser en principio atribuidos a la influencia de Jerónimo Gracián, la forma dialógica y la estructura de la sección de la obra dedicada a la oración, proceden en realidad de otras fuentes y del propio ingenio de la escritora.

Confluyeron, por tanto, para la posibilidad del desarrollo de esta obra, el carácter independiente de la monja y unas circunstancias personales favorables, al menos en un principio. No podemos decir que su escritura obedezca únicamente a un carácter más independiente de la escritora o que su escritura se haya podido producir sólo gracias a sus avatares personales. Todo ello, nos hace plantearnos si debemos revisar con más atención los textos de estas escritoras, en vez de etiquetarlas, también nosotros, al igual que muchos de sus superiores, dentro del membrete de «escritoras por obediencia». Creo que es fundamental descubrir la relación real que tenía cada una de estas religiosas con sus confesores o narratarios, las influencias culturales de la escritora y el sub-texto que pueda existir tras frases en apariencia sometidas al modelo inicial.

Es indudable María de San José tomó un camino que para algunos de sus superiores fue considerado como peligroso, no tanto por su escritura (aunque también pudiese influir negativamente) como por sus decisiones personales dentro de la Orden. Todo ello le llevó a vivir una existencia no exenta de dificultades, pero que al menos nos ha dejado un rico legado literario del que queda todavía mucho que explorar.

${ }^{123}$ A. Weber, Teresa of Avila and the rhetoric of femininity, Princeton University Press, 1990, pág. 36.

${ }^{124}$ S. Herpoel «Al fin soi muger», pág. 800; S. Schlau, op. cit., pág. 283. 
